Jurnal At-Tibyan: Jurnal Ilmu Alqur'an dan Tafsir

Volume 6 No. 2, Desember 2021 (p. 323-341)

P ISSN 2442-594X | E ISSN 2579-5708

http://journal.iainlangsa.ac.id/index.php/tibyan

\title{
THE CONCEPT OF TEACHER IN THE QURAN AND ITS RELEVANCE TO HIS FUNCTION IN THE DIGITAL ERA
}

\author{
Anwar Mujahidin \\ Institut Agama Islam Negeri Ponorogo, Indonesia \\ anwarmujahidin@iainponorogo.ac.id \\ Yufridal Fitri Nursalam \\ Institut Agama Islam Negeri Ponorogo, Indonesia \\ yufridal@iainponorogo.ac.id \\ Ju'subaidi \\ Institut Agama Islam Negeri Ponorogo, Indonesia \\ jusubaidi@iainponorogo.ac.id \\ DOI 10.32505/at-tibyan.v6i2.3280 \\ Submitted: 13-09-2021 $\quad$ Revised: 18-12-2021 $\quad$ Accepted: 26-12-2021
}

\begin{abstract}
In today's digital technology era, teachers' function in the learning process seems obscure. They are only perceived as learning facilitators. This paper attempted to find relevant teacher's concepts in the digital era according to the interpretation of the Qur'an. The perspective of the Qur'an interpretation needs to be studied as a source of knowledge to find teacher's concepts relevant to the digital era because the existing studies on teachers tend to be based on partial perspective between theory and norm. It was conducted under the interpretation of the Qur'an on the development and internalization of science. The interpretation of some verses was analyzed for contextuality and its implications on the function of teachers in the current era. The study results suggested that a teacher should function as an educator and caregiver. $\mathrm{He} / \mathrm{she}$ not only teaches science but also directs and nurtures students, so they understand and practice moral goodness. Education is responsible for developing not only cognitive but also psychomotor skills. It must also improve students' knowledge of goodness and virtue so that they can practice it in the end. That the function of a teacher is to educate and nurture students to be a good human is yet relevant today. This paper suggested a deeper research to examine the decline in the role of teachers around the school environment by evaluating the curriculum and learning system.
\end{abstract}

Keywords: Teacher's Function, Thematic Interpretation, Digital Era, Education Purpose

Copyright @ 2021. Owned by the Author, published by Jurnal At-Tibyan: Jurnal Ilmu Alqur'an dan Tafsir. Articles with open access. License: CC-BY 


\begin{abstract}
Abstrak
Fungsi guru dalam pembelajaran di era teknologi digital nampak kabur. Guru dipandang hanya sebagai fasilitator dalam pembelajaan. Tulisan ini merupakan usaha menemukan konsep guru menurut tafsir al-Quran yang relevan di era digital. Perspektif tafsir perlu dikaji sebagai sumber ilmu untuk menemukan konsep guru yang relevan dengan era digital karena kecenderungan studi tentang guru yang ada masih berdasarkan persetif yang parsial antara perspetif teoritis dan normative. Tulisan ini didasarkan pada data berupa tafsir al-Quran terhadap ayat-ayat al-Quran tentang pengembangan dan internalisasi ilmu. Tafsir ayat akan dianalisis kontekstualitas dan implikasinya kepada fungsi guru di era digital. Hasil penelitian menunjukkan bahwa fungsi guru dalam al-Quran adalah pendidik sekaligus pengasuh. Guru tidak hanya mengajar ilmu pengetahuan, namun guru juga mengarahkan dan mengasuh peserta didik sehingga mengerti dan mengamalkan kebaikan moral. Tujuan pendidikan tidak hanya aspek kognitif yakni pengetahuan dan psikomotorik yakni ketrampiran siswa. Pendidikan juga harus menjadikan siswa memiliki pengetahuan akan kebaikan dan kebajikan sehingga mengamalkannya. Fungsi guru untuk mendidik dan mengasuh siswa sehingga menjadi manusia seutuhnya tersebut menjadikan fungsi guru tetap relevan di era digital. Tulisan ini menyarankan perlu penelitian yang lebih dalam untuk mencermati penurunan peran guru dilingkungan sekolah dengan mengevaluasi kurikulum dan system pembelajaran di sekolah.
\end{abstract}

Kata Kunci: Fungsi Guru, Tafsir Tematik, Era Digital, Tujuan Pendidikan

\title{
Introduction
}

Currently, in the digital era, the use of technology in education leads the role of teacher to be bias. Technology does not only function for the delivery of teaching content, but it replaces several roles of teachers, which is providing assistance for instruction and learning resources. Students can easily discover knowledge from various sources on the internet ${ }^{1}$. The center of learning no longer lies on the teacher but students. The function of teacher has declined, no longer a role model and a source of student knowledge.

Studies on a teacher have so far focused on three aspects. The first aspect is a shift on the role, as a professional who controls the learning process. A teacher is seen as a transmitter of knowledge to students. The effectiveness of delivering material depends on "the ability of the teacher to attract, motivate, and instruct" ${ }^{2}$. A teacher is

\footnotetext{
${ }^{1}$ Muhammad Iqbal and Muhammad Irfan Arif, "Globalization and Paradigm Changes in Teacher Education: Revolutionizing Teaching Learning Process at School Level in Pakistan.," International Education Studies 4, no. 4 (2011): 99-110, https://doi.org/10.5539/ies.v4n4p99.

${ }^{2}$ Nandita Shenoy, K. Ashok Shenoy, and U. P. Ratnakar, "The Perceptual Preferences in Learning among Dental Students in Clinical Subjects," Journal of Clinical and Diagnostic Research 7, no. 8 (2013): 1683-85, https://doi.org/10.7860/JCDR/2013/4940.3219.; Kanchi Shah et al., "How Different
} 
also viewed as a facilitator and informant of the learning process ${ }^{3}$. The second is quality improvement, both internal and external factors ${ }^{4}$. The third is teachers' role in responding to various sociocultural and religious issues, such as radicalism prevention ${ }^{5}$ and social justice realization ${ }^{6}$. The three research tendencies see the concept of the teacher in a pedagogical dialectic solely that their role depends on the objective factors within in the relationships of learning. The tendency did not see the concept of the teachers who possess subjective relationship with social and religious norms.

This paper aims to complement the shortcomings of previous studies which do not put any concern on the construction of the teacher concept based on the Qur'an. The concept of the Qur'an is a paradigm that could generate a new way of seeing a problem. This article will examine the verses of the Qur'an that discuss about the process of developing and internalizing knowledge. The Qur'an understandings regarding the internalization of science will construct the concept of the teacher, that three questions are constructed: how the Qur'an verses about the development and internalization of science are interpreted; what is the context of the interpretation of the verses that discuss about the development and internalization of science with learning systems in the digital era; and how the Qur'an interpretation implies on the function of teachers in the digital era.

The current paper, on the relevance of the concept of the teacher in the Qur'an with the function of the teacher in the digital era, is conducted under three arguments. First, the Qur'an has a number of verses that discuss about the development and internalization of science in to human beings, so they know and master the science. The concepts of science discussed in the Qur' an are horizons of understanding that can construct the concept of teacher. The Qur'an paradigm of teachers is the basis for seeing the relevant functions of teachers in the digital era.

This paper is a literature or library research examining the interpretation of verses containing a discussion of the process of developing and disseminating knowledge. The verses studied were selected based on their content that met the

Are Students and Their Learning Styles?," International Journal of Research in Medical Sciences 1, no. 3 (2013): 1, https://doi.org/10.5455/2320-6012.ijrms20130808.

${ }^{3}$ Iqbal and Arif, "Globalization and Paradigm Changes in Teacher Education: Revolutionizing Teaching Learning Process at School Level in Pakistan."

4 Ade Rustiana, Wisudani Rahmaningtyas, and Malinda Listia Astuti, "The Effect of Academic Qualification, School Facilities and Compensation on Teacher Professional Competency," Dinamika Pendidikan 13, no. 2 (2018): 157-70, https://doi.org/DOI: 10.15294/dp.v13i2.18328.; Miska Gewasari, Belferik Manullang, and Abdul Muin Sibuea, "The Determinant Factors That Effect Teacher Performance of Public Senior High School in Deli Serdang District.," IOSR Journal of Research \& Method in Education (IOSRJRME) 07, no. 01 (2017): 12-21, https://doi.org/10.9790/7388-0701041221; Rosita Endang Kusmaryani et al., "Key Factors in Teacher Professional Development," 2nd Psychology and Humanity, no. July 2014 (2016): 704-8.

${ }^{5}$ Irham Irham, Sansan Ziaul Haq, and Yudril Basith, "Deradicalising Religious; EducationTeacher, Curriculum and Multiculturalism," Epistemé: Jurnal Pengembangan Ilmu Keislaman 15, no. 1 (2020): 39-54, https://doi.org/10.21274/epis.2020.15.1.39-54.

${ }^{6}$ Raihani, “A Model of Islamic Teacher Education for Social Justice in Indonesia a Critical Pedagogy Perspective," Journal of Indonesian Islam 14, no. 1 (2020): 163-86, https://doi.org/10.15642/JIIS.2020.14.1.163-186. 
criteria for the research focus, which was about the figures involved in the process of knowledge development. The figures in the educational process covered conveying knowledge, wisdom, and religious teachings and developing the students' potential. This study included both conceptual and narrative verses with philosophical, methodological, and practical concepts.

The research data were the interpretations of the Qur'an verses. Firstly, we tracked verses relevant to the research problem using mu'jam al-mufahras li al-fạ alQurān. The interpretive data were the meaning of the term or parts of the verses and the meaning of the verses relevant to the research problem. Contextual meaning was derived from the relationship of the verse interpretation with contemporary literature in educational systems. The data of verses and their interpretations were classified thematically to reinforce the concept of teachers and their role in the learning process in the digital era. Data classification was carried out not only on the basis of themes but also by considering the aspects covered. The context of the verse on the current education system was analyzed based on philosophical and functional parameters.

The data was analyzed by using text analysis method with explanatory analysis approach, describing and criticizing the substance of the content according to the categories in the research problem ${ }^{7}$.

\section{Maudūi Interpretation of Education}

Previous studies suggested that Qur'an interpretation with the thematic method had discussed the meaning of the Qur'an verses which have similar topic in one complete and comprehensive discussion topic. The topic of education has also been interpreted by using maud $\bar{u}$ ' $\bar{i}$ method, from the terms that already exist in the Qur'an, such as ta'tim, science, reason, to various theoretical concepts under social phenomena, for example learning methods in the Qur'an. The results of maudū' 'i study which discuss about the paradigmatic concepts become a material for discussion in enriching the thinking of various concepts in the field of education. Literature discussion regarding maudu $\bar{u} \bar{i}$ interpretation in the field of education can be dissected at least in three orientations, maudu '̄i interpretation development in discussing issues of education, the concept of teachers, and the digital era.

Maudu $\bar{u}$ ' interpretation is defined as an approach of the Qur'an interpretation by collecting the verses of particular theme, sorted according to the chronicle of their revelation (al-tartīb al-nuzulī) and then examined under the socio-historical context and the relevance of the verses one another ${ }^{8}$. It is a systematic discussion of interpretations compiled based on a single theme of discussion. It is related to scientific reasoning and systematic and coherent discussion. The interpreter has an academic question about an issue in a particular field, collects the verses of the Qur'an

\footnotetext{
${ }^{7}$ Sahiron Syamsuddin, Tafsir Studies (Yogyakarta: eLSAQ, 2009).

${ }^{8}$ A. H Al-Farmawi, Al-Bidâyah Fî At-Tafsî̀ Al-Maudhû̀' î (Mesir: Maktabah Jumhuriyah, 1977); M. Anwar Syarifuddin and Jauhar Azizy, "Thematic Scientific Interpretation of the Qur'an in Indonesia," Atlantis Press 137, no. Icqhs 2017 (2018): 43-50, https://doi.org/10.2991/icqhs-17.2018.7.
} 
spread in many letters of the common theme, and then interprets them systematically. Maud $\bar{u}$ 'i interpretation refers to the approach to the Qur'an interpretation by collecting verses with certain themes, sorting them according to the chronicle of revelation (altartīb al-nuzuli), and then studying through socio-historical context and their relevance with one another. It is a systematic discussion of the interpretation based on a single theme. It is related to scientific reasoning and systematic and coherent discussion. The interpreter holds an academic question about a problem in a particular field, collects the verses of the Qur'an available in many surah with a general theme, and then interprets them systematically.

In contrast to the concept above, Quraish Shihab views that thematic approach is not merely interpreting the Qur'an on a particular topic in a complete and contextual way, but it is also expected to provide moral solutions for social problems ${ }^{9}$. He emphasizes that in selecting problems or topics studied through maudū' $\bar{i}$ interpretation, they should prioritize issues that touch the community and are directly experienced by them ${ }^{10}$.

Maud $\bar{u}, \bar{i}$ interpretation is perceived different from scientific interpretation. It tends to talk about daily practical themes or problems, in both general and religious life. It is a method of interpretation that discusses verses related to scientific concepts. It is initially limited to discussing verses about the natural sciences or commonly called ayat kauniyah, uncovering the mystery of knowledge about the universe. Along with the development of scientific interpretation, it also discusses various themes across scientific disciplines, such as astronomy, medicine, architecture, algebra, agriculture, and astrology ${ }^{11}$.

Both Maudu' 'i and scientific interpretation discuss the verses of the Qur'an with an approach to collecting verses with certain theme. As for the difference in the preference of theme, whether it is related to the concepts of nat ural sciences or social sciences is a problem that involves differences in approaches and theoretical frameworks. Maudu 'í interpretation and scientific interpretation can be merged into one term called thematic interpretation with a scientific approach. Various thematic concepts discussed in the verses of the Qur'an are linked to the themes of discussion, either natural or social sciences ${ }^{12}$.

Mauḍ' 'i interpretation in the field of education can also be called tarbawi interpretation. It discusses about the perspective of the Qur'an on fundamental themes in education. It mainly discusses about issues related to theoretical and practical

\footnotetext{
9 M. Quraish Shihab, Membumikan Al-Quran, Fungsi Dan Peran Wahyu Dalam Kehidupan Masyarakat (Bandung: Mizan, 2007).

${ }^{10}$ Shihab.

${ }^{11}$ Theo Jaka Prakoso, "Validitas Tafsir Bi Al-Ilmi Dalam Penafsiran Ayat-Ayat Penciptaan Alam," Studi Ilmu-IImu Al-Quran Dan Hadist 21, no. 1 (2020), https://doi.org/, doi: 10.14421/qh.2020.2101-04.

${ }^{12}$ Syarifuddin and Azizy, "Thematic Scientific Interpretation of the Qur'an in Indonesia."; Anwar Mujahidin, "The Dialectic of Qur'an and Science: Epistemological Analysis of Thematic Qur'an Interpretation Literature in the Field of Social Sciences of Humanities," ESENSIA: Jurnal Ilmu-Ilmu Ushuluddin 19, no. 2 (2018): 209, https://doi.org/DOI: https://doi.org/10.14421/esensia.v19i2.1563.
} 
thought of education. Tarbawi interpretation perceives that Qur'an has a collection of verses that talk about the nature of humans, their strengths and weaknesses, and the way they achieve excellence through the educational process. Philosophical problems about humans are an inherent part of the philosophy of education. If the interpretation of the verse is positioned within the framework of education, it can formulate the concept of human nature as the subject and purpose of education ${ }^{13}$. In addition to philosophical and theoretical concepts about education, Maudu $\bar{u}$ interpretation also connects the verses of the Qur'an with the theme applied in the field of education. The verses of the Qur'an that discuss about the way to deliver Islamic messages to humans can be related to learning methods and strategies ${ }^{14}$.

Tarbawi interpretation seems exclusive because the themes studied are limited to only Islamic Education. This assumption is not completely correct because the Qur'an as a source of knowledge and Islamic thought is open (rahmatan lil 'älaminn). The thoughts developed from the Qur'an contributed to changes in general concepts. Tarbawi interpretation as a part of contextual interpretation can be oriented inclusively by trying to find answers to problems in the field of education, such as the concept of reason ${ }^{15}$, the concept of soul $^{16}$, and the learning methods under the perspective of the Qur' an ${ }^{17 .}$

\section{The Role of Teacher}

Previous studies have shown that there has been a shift in the learning concept along with the changes in the educational paradigm from the teacher as the center to the student as the center. The teacher's role as a source of knowledge has been replaced by a variety of diverse sources mediated by digital technology. The internet and social media provide easy access for students to sources of information and knowledge needed. The teacher's role is only as a facilitator, moderator, and evaluator. In various studies on the role of teachers in the digital era, the discussion tends to focus on three aspects, the impact of the internet on teachers, the efforts to increase teacher

${ }^{13}$ Ali Mudlofir, "Tafsir Tarbawi Sebagai Paradigma Qur'ani Dalam Reformulasi Pendidikan Islam," Al-Tahrir: Jurnal Pemikiran Islam 11, no. 2 (2011): 261, https://oi.org/10.21154/al-tahrir.v11i2.35; Anwar Mujahidin, "Integrative Education Paradigm Based on Local Culture; Analysis of Contextual Interpretation of Qur'anic Verses on the Purpose of Human Creation," Atlantis 261, no. Icie (2018): 163-68; As'aril Muhajir, "Tujuan Pendidikan Dalam Perspektif Al-Qur'an," Al-Tahrir: Jurnal Pemikiran Islam 11, no. 2 (2011): 237, https://doi.org/10.21154/al-tahrir.v11i2.34.

14 Subur, "Materi, Metode, Dan Evaluasi Pembelajaran Dalam Perspektif Al-Qur'an," Jurnal Penelitian Agama 16, no. 2 (2015): 199, https://doi.org/10.24090/jpa.v17i1.2016.pp43-72.

${ }^{15}$ Ade Jamaruddin, "Exsistensi Fungsi Akal Manusia Perspektif Al- Qur'an," An-Nur 4, no. 1 (2015): 77-110.

16 Sahidi Mustafa Mustafa, “Konsep Jiwa Dalam Al-Qur'an,” Tasfiyah 2, no. 1 (2018): 123, https://doi.org/10.21111/tasfiyah.v2i1.2485.

17 Abdul Haris Pito, "Metode Pendidikan Dalam Al-Qur'an," Andragogi: Jurnal Diklat Teknis Pendidikan Dan Keagamaan 7, no. 1 (2019): 113-29, https://doi.org/10.36052/andragogi.v7i1.74. 
professionalism through training, workshops, and advanced studies, and the innovation and creativity of teachers in the classroom ${ }^{18}$.

The main role of a teacher for students lies in the cultivation of morals. Al-Attas stated, "Education in Islam is the process of instilling adab (morality) into Muslims. $A d a b$, according to al-Attas, includes the material and spiritual life of human beings ${ }^{19}$. The conception of tadib (respect) leads Islamic education to be more oriented to building individuals with noble character without compromising the intellectual abilities and skills of each student through the stages of integrative teaching ${ }^{20}$. AlAttas view on Islamic education is in line with the national education objectives to create Indonesians as a whole, human development on not only cognitive aspects but also independence and morality or character. ${ }^{21}$

Teachers in the digital era put more emphasis on the adaptation to the use of technology. Although the learning process in the digital era emphasizes students to actively collaborate with their fellows and all activities are student-centered, students still need teacher facilitation that the learning implementation runs properly. The teacher's role is called a self-regulated learning strategy with three stages. 1) Forethought (thinking), teachers prepare their teaching, set teaching goals, plan their actions, regulate learning strategies and teaching materials wider both offline and online with digital literacy that is audio-visual. 2) Performance, during classroom instruction, the teacher monitors students' understanding, identifies, and resolves misunderstandings. In the performance stage, students solve problems by applying the information obtained at the forethought stage. 3) Self-reflection, teachers evaluate the effectiveness of their instructions and the teaching strategies used, as well as evaluate students' understanding on the knowledge constructed together. Self-reflection is the stage where students evaluate their understanding during the learning process. Then students discuss it again with friends or teachers to improve their understanding. Finally, students make conclusions from what they have learned ${ }^{22}$.

According to Mardianto, the role of teacher in the digital era is more functional where the teacher works as a learning facilitator. The study does not concern on the

18 Jayendrakumar N. Amin, "Redefining the Role of Teachers in the Digital Era," International Journal of Indian Psychology 3, no. 3 (2016), https://doi.org/10.25215/0303.101.

${ }^{19}$ A. Ghoni, "Pemikiran Pendidikan Naquib Al-Attas Dalam Pendidikan Islam Kontemporer," Jurnal Lentera: Kajian Keagamaan, Keilmuan Dan Teknologi 3, no. 1 (2017): 196-215.

20 Putri Lestari, Nurul Iman, and Katni Katni, "Pemikiran Pendidikan Islam Syed Muhammad Naquib Al-Attas (Tinjauan Paradigmatik Dan Implementatif Konsep Ta'dib Dalam Pembelajaran Agama Islam Pada Tingkat SMA/MA)," TARBAWI:Journal on Islamic Education 3, no. 1 (2019): 17, https://doi.org/10.24269/tarbawi.v3i1.208.

${ }^{21}$ Sri Syafa'ati and Hidayatul Muamanah, "Konsep Pendidikan Menurut Muhammad Naquib AlAttas Dan Relevansinya Dengan Sistem Pendidikan Nasional," Palapa:Jurnal Studi Keislaman Dan Ilmu Pendidikan 8, no. 2 (2020): 285-301, https://doi.org/10.36088/palapa.v8i2.859.

${ }_{22}$ Mardianto, "Peran Guru Di Era Digital Dalam Mengembangkan Self Regulated Learning Siswa Generasi Z Untuk Pencapaian Hasil Pembelajaran,” Prosiding Seminar Nasional \& Call Paper, 2019, $150-57$. 
teacher's role as an irreplaceable source of knowledge ${ }^{23}$. His study on student's relationships with others in learning found that students generally seek for help of others in learning not to solve their problems but to increase their own mastery of knowledge. He observed that preschoolers often called on others for guidance when they faced challenging assignments. They relied on others they know could provide superior examples or performance of what they were trying to do. Their motive for involving adults is knowledge oriented, not reward oriented. They address adults as teachers, not as tools. They perceive the teachers (either parent, instructor, older sibling, etc.) as a primus inter pares: an agent of the same kind as himself, but someone with more advanced skills and knowledge ${ }^{24}$.

\section{Digital Era}

Digital era is defined as the era of communication technology through smartphones, laptops, and gadgets with various features supported by the internet network that allows people to connect with one another. They are not only limited to having conversation but also exchanging photos, videos and emoticons, as a form of expression to one another. The definition emphasizes two concepts, a fast network and complete content. The digital age is associated with rapid information traffic. Information concerns all aspects of life. Children becomes more accustomed to screens than paper books, and adults are becoming attached to electronic devices. They are unexpectedly forced to publish their life on social networks ${ }^{25}$.

Technology can benefit or harm one's life that it requires literacy. Negatively, it raises dependence on cellphones, gadgets and laptops. Today, it is used for everything from enjoying entertainment and communications to extracting data and assisting various purposes, such as preventing war and gaining political support. All information and knowledge can be easily exchanged between one person with another in many different places quickly. In addition to dependence, it can also lead to liberation. Humans no longer depend on each other; students no longer depend on teachers; markets no longer depend on places and people who sell because everything can be replaced with technology. This phenomenon is detrimental to the human capacity for creativity, critical thinking, and language expression. The use of technology requires literacy so that we are not dependent on the tools and use them in a wise, safe and ethical way. Therefore, digital literacy includes issues of privacy, security, and ethic ${ }^{26}$.

\footnotetext{
${ }^{23}$ Henrike Moll, "How Young Children Learn from Others," Journal of Philosophy of Education 54, no. 2 (2020): 340-55, https://doi.org/10.1111/1467-9752.12417.

${ }^{24}$ Moll.

25 Andrea E. Cladis, "A Shifting Paradigm: An Evaluation of the Pervasive Effects of Digital Technologies on Language Expression, Creativity, Critical Thinking, Political Discourse, and Interactive Processes of Human Communications," E-Learning and Digital Media 17, no. 5 (2020): 34164, https://doi.org/10.1177/2042753017752583.

26 Luci Pangrazio, Anna Lena Godhe, and Alejo González López Ledesma, "What Is Digital Literacy? A Comparative Review of Publications Across Three Language Contexts," E-Learning and Digital Media 17, no. 6 (2020): 442-59, https://doi.org/10.1177/2042753020946291.
} 
The positive use of digital technology in the world of education is increasingly recognized. Teachers are required to change their learning strategies that provide opportunities for students to use digital resources and media. They must select, develop, and enrich teaching and learning materials in a digital structure ${ }^{27}$. Internet has proven to be effective for $d a^{\prime} w a h$. Some applications, such as YouTube and Facebook, can be used by Muslim scholars to spread the content of lectures that have been recorded. People can also choose various themes according to their interests ${ }^{28}$.

\section{Education Terms in Indonesia Qur'an interpretation}

The verses on the development and internalization of knowledge contain conceptual teachings and stories. Conceptually, the process of internalizing knowledge in the Qur'an is expressed in terms of tarbiyah and ta'tim. In addition, there are also verses that indirectly explain the concept of learning and the figure who plays an active role in education with particular terms, such as apostles, prophets, scholars, and people who have superior characteristics in terms of knowledge and intelligence ( $\bar{l} l u l$ $a l b \bar{a} b)$. The story includes, the story of Moses studying with Khidzir, Luqman advising his son and the interpretation of verses about the apostles, prophets, and scholars. Interpretations related to the concept of the teacher and the story will be discussed in the following sections.

According to the Qur'an, learning covers a very broad and deep dimension of human aspects. The comprehensive discussion of the learning objectives is gained through terms such as tarbiyah, ta'tim and fiqh. The term tarbiyah is rooted in the word rabba yurabby. Quraish Shihab in his interpretation of the verse of Al-fatihah, which reads alhamdulilläh rab al- 'ālamin, explains the meaning of the rabb related to education. The word $r a b$ whose root word is tarbiyah, aims to direct something step by step towards the perfection of its occurrence and function. The word rabbi $\bar{i}$ also means to have, although the first opinion is better, moreover Allah's ownership is explicitly mentioned in the fourth article of this verse. When mentioning the word $r a b b$, in the meaning of this word, all the attributes of Allah that can touch creatures are covered ${ }^{29}$. Hamka in his interpretation of al-Azhar also agrees with Quraish Shihab that the word rabbun includes the nature of Allah as an educator and caregiver ${ }^{30}$.

The definition of rubübiyah (education or maintenance) covers the provision of sustenance, forgiveness and love, as well as anger, threats, torture, and so on. This meaning is close to our minds when threatening, even hitting our children, in order to educate them. Even though the child feels that he has been treated unfairly, later when

\footnotetext{
${ }^{27}$ Amin, "Redefining the Role of Teachers in the Digital Era."

28 Muhammad Munir, "Fenomena Dakwah Online Dan Offline Ustadz Abdus Somad Di Pondok Pesantren Al-Amien Prenduan Sumenep Madura Pendahuluan Ketenteraman Dalam Kehidupan Masyarakat Merupakan Salah Satu Harapan Seluruh Masyarakat Didunia, Tidak Juga Masyarakat Yang Di Kehidupa," Islamic Management and Empowerment 1, no. 1 (2019): 129-42.

${ }^{29}$ M. Quraish Shihab, Tafsir Al-Miṣbāh Pesan, Kesan Dan Keserasian Al-Qưran, Vol.1 (Jakarta: Lentera Hati, 2008),30-31

${ }^{30}$ Hamka, Tafsir Al-Azhar, Juz 1 (Jakarta: Gema Insani, 2015),66
} 
he grows up, he will realize that the beating is good for him. So, whatever the form of God's treatment to us, we must believe that this is completely inseparable from the nature of His care and education, even though we sometimes judge it negatively by our limited reasons ${ }^{31}$.

The purpose of learning is also explained in the Qur'an with the term ta'Tim as in al-Baqarah 30, wa 'allama Adam al-Asmā, and He, Allah, teaches Adam the names of the entire objects. The verse informs that humans are gifted by God with the potential to know the names or functions and characteristics of objects, for example the function of fire, the function of wind, and so on. Humans are also gifted with the potential to speak. The system of teaching language to humans (young children) does not start by teaching verbs but names. It is papa, it's mama, they're eyes, it's a pen, and so on ${ }^{32}$.

Hamka connects the beginning of al-Baqarah 30 with the potential of knowledge, which is through reason. The previous verse explains the position of humans as caliphs to govern the earth and reveal the hidden secrets within. Then, a miraculous and unseen mind is granted to humans. The form of reason is not visible, but the trace that shows the existence of reason exists, which is science. Extensive knowledge is not given all to one person and is not given all at once, but from the results of their own investigations and research ${ }^{33}$.

Quraish Shihab in his interpretation on al-Baqarah 31 also reviews the learning process. Teaching is not always dictating something or conveying a word or idea, but it can also be in the sense of honing the potential possessed by students so that in the end the potential is honed and can generate a variety of knowledge. Whatever the meaning of this verse, it is clear that one of the privileges of human beings is their ability to express what comes to their mind and to grasp language so that it leads them to know something. On the other hand, human ability to formulate ideas and give names to things is a step towards the creation of knowledgeable humans and the birth of knowledge ${ }^{34}$.

Another concept that explains learning is the word Tafaqquh, as contained in surah al-Taubah 122. The word liyatafaqqahu is derived from the word fiqh, which refers to deep knowledge regarding difficult and hidden things. Not merely knowledge, the addition of the letter "ta" to the word implies seriousness of effort. The serious effort may lead the actors to be experts in their fields. The word invites Muslims to become experts in knowledge. The word fiqh is not limited to what is termed in the discipline Islamic religious laws which are practical and obtained through reasoning on detailed arguments, but it also covers all kinds of profound knowledge. The association of tafaqquh (the deepening of knowledge) with religion seems to underline the purpose of the deepening, not in terms of knowledge of religion. At the time of the Qur'an revelation, people did not know the division of religious and general science, even it

\footnotetext{
${ }^{31}$ Shihab, 2008, Vol. 1, 30-31

${ }^{32}$ Shihab, 2008, Vol.1, 145-146

${ }^{33}$ Hamka, 2015, Juz 1, 135

${ }^{34}$ Shihab, 2008, Vo.1, 147
} 
was not introduced by Allah. Allah does not distinguish between them in the Qur'an. People at that time did not know the terms religious knowledge and general science because all knowledge came from Allah. Qur'an only introduced that there is knowledge obtain though effort (acquired knowledge) and knowledge directly given by God without human effort (laduni/perennial) ${ }^{35}$.

When explaining the duty of the messenger, who was ummy, to read the book in surah al-Jumuah, Quraish Shihab quoted Imam Fakhruddin al-Razi's opinion that human perfection was obtained by knowing the truth and virtue and practicing them. Humans have the potential to know theoretically and practice practically. Allah sent down the holy book and sent the Prophet Muhammad. to lead people to achieve them. The sentence (which is part of the verse), "read the verses of Allah", means that the prophet Muhammad conveyed what he received from Allah to mankind. Whilst, purification means perfection of theoretical potential by acquiring divine knowledge. And, teaching the Qur'an is a sign of teaching the external knowledge of Sharia. Alhikmah refers to knowledge of the beauty, secrets, motives, and benefits of the Sharia. ${ }^{36}$.

Quraish Shihab also quoted Abduh's opinion which is different from that of alRazi. He sees Allah's verses with those of kauniyah which show His power, wisdom, and oneness. Reading these verses means explaining and directing the human soul to benefit and learn from it. Purifying their souls means cleansing their souls from great beliefs, moral impurity and others that are rampant during the ignorance period. Teaching the Qur'an means teaching how to write with a pen because Islam requires learning to write with a pen and frees them from illiteracy. Religion encourages (revival) civilization, and regulates the affairs of the people. Wisdom means secret (religious) issues, legal knowledge, explanations about benefits and the way to practice them ${ }^{37}$.

Quraish Shihab also quoted Abduh's opinion which is different from that of alRazi. He sees Allah's verses of kauniyah show His power, wisdom, and oneness. Reading the verses means explaining and directing the human soul to benefit and learn from them. Purifying their souls means cleansing from great beliefs, moral impurity and others that are rampant during the ignorance period. Teaching the Qur'an means teaching how to write with a pen because Islam requires learning to write with a pen and frees them from illiteracy. Religion encourages (revival) civilization, and regulates the affairs of the people. Wisdom means secret (religious) issues, legal knowledge, explanations about the benefits and the way to practice them.

\section{Teacher Competence}

An educator is explained in surah al-Isra 24, "kamā rabbayānī sagïra". The verse guides children to pray sincerely, "O my Lord, who nurtures and educates me, among

\footnotetext{
${ }^{35}$ Shihab, 2008, Vo. 5, 750

${ }^{36}$ Shihab, 2008,Vol.14, 220

${ }^{37}$ Shihab, 2008,Vol.14, 220
} 
others, by instilling love in my parents, love them both, because or as they both have bestowed love on me, among others, by educating me when I was little ${ }^{38}$. Surah Al-Isra 18 also employs the term from the word rabba yuraby, namely nurabby, "Qāla alam nurabbika finna walidan". "Didn't we take care of you among our family when you were a baby?" This part of the verse explains about the reminder of Pharaoh to Moses who would allegedly rebel against him, so he reminded Moses about his past, which was considered a merit, that he had raised Moses ${ }^{39}$.

In surah 'Ali 'Imran 79, the figure of a person considered to have rabbinic characteristics is described. The word rabbany is taken from the word rabb which has various meanings, including educator and protector. If this word stands alone, it means none other than Allah. If you want to attribute the word into an object, this word is usually added with the letter " $y a$ ", such as the word insān to be insāny or nür to be nüry. Those who are blessed with books, wisdom, and prophethood encourage everyone to become rabbany, in the sense that all activities, movements and steps, intentions, and speeches are all in line with the values commanded by $\mathrm{Allah}^{40}$.

The word tadrusun, which is a part of the verse, is used to examine something to take advantage of it. In the context of the text, both in the scriptures and others, it discusses about the text to draw the information and messages within. Rabbany, according to this verse, at least does two things: first, always teaching the scriptures, and second always studying them. Rabbany must always teach because humans are never free from weakness. On the other hand, rabbany is in charge of continuously discussing and studying the scriptures. Somebody should not stop studying, researching, and discussing whether the object is the universe or the scriptures. What he or she find in the discussion and research should also be taught, so teaching and researching meet in an unbroken circle or else he or she passes away. The Qur'an emphasizes the loss of people who do not testify to one another about truth and fortitude, which is teaching each other about knowledge and guidance and reminding one another about the need for fortitude in life ${ }^{41}$.

The derivative of the word 'allama yu'allimu is 'allim. In the Qur'an, the term 'àlim is written in plural, 'ulama. Surah Fattir 28 explains that the word ulama is the plural form of 'alim, whose root word means to know clearly. All of the words from the letter ain, lam and mim always refer to clarity, such as alam which means flag, alam which means the universe or creatures that has a taste and or intelligence and alama which means address. Many religious experts understand the word 'ulama in the sense of studying religion. When viewed in terms of the use of Arabic, the meaning of the word 'ulama, as an expert in religious knowledge, is not absolutely the case. Whoever has knowledge in any discipline, we can call him/her 'alim.

\footnotetext{
${ }^{38}$ Shihab, 2008,Vol.7, 453

${ }^{39}$ Shihab, 2008,Vol.10, 21

${ }^{40}$ Shihab, 2008,Vol.2,133-134

${ }^{41}$ Shihab, 2008,Vol.2,134
} 
Another term used by the Qur'an is wa'idhzin which is in Surah al-Shu'arā 136. Al-wä'idhzīn is the plural form of the word al-wäidhz which gives wa'adhz or a heart touching speech that contains good promises and threats. This part of the verse is connected with the next part of the verse, khulüq, which means a strong psychological potential within a person, which leads him to generate various behaviors easily and without being made up. This potential is developed through education, training, and example. If it is positive, it grows good morals, and it does on the other around. Hud's words about al-wa'idhzin may refer to two ways, praise to the previous generation, their ancestors who have left for the next generation commendable deeds, and thus they as the next generation will continue to maintain and carry on everything that has been performed, practiced commendably by the older generation.

The next concept related to the mastery of science is $\bar{u} l i l$ al-bāb. Quraish Shihab, in his interpretation on Surah al-Māidah 100, explains that $\bar{u} l i l$ al-bāb is the plural form of $1 u b b$, which means the essence of something. A peanut, for example, has a skin that covers the contents. The bean filling is called lubb. Ulil al-bāb refers to people who have a pure mind, which is not covered by skin, which is the fog of ideas that can create confusion in thinking. A person who meditates on Allah's decrees and implements them is expected to achieve good fortune, and whoever rejects it, there must be confusion on his/her way of thinking ${ }^{42}$.

\section{Scope of Learning Materials}

Quraish Shihab explains the concept of wisdom in Surah al-Baqarah 269. Wisdom is derived from the word hakama, which originally means "to hinder". From the same root word, a word which means "to control" is formulated. It refers to something whose function is to lead to the good and avoid the bad. To achieve this goal, knowledge and the ability to apply it are needed. Wisdom is understood as knowledge of good and bad, as well as the ability to apply the good and avoid the bad $^{43}$. Quraish Shihab also explains the concept of wisdom in surah Luqmān. Wisdom is something that when we use/care for it, it will prevent harm or difficulty. Choosing the best and the most appropriate is the embodiment of wisdom. The culprit is named hakim, who is right in his judgment and arrangements. He is the judge. The Qur'an is hakim because all of its contents are the best instructions to bring benefit and avoid evil $^{44}$. Scholars suggest various explanations about the meaning of wisdom. One of which is hikmah, which means "knowing the most important of all things, both knowledge and deeds. Wisdom is the science of amaliah and scientific charity. It is knowledge supported by charity and a proper charity is supported by science.

According to Hamka in the interpretation of al-Azhar, wisdom is broader than knowledge, even the end of knowledge is the beginning of wisdom. Wisdom can also

\footnotetext{
${ }^{42}$ Shihab, 2008,Vol.3, 115

${ }^{43}$ Shihab, 2008,Vol.1, 581

${ }^{44}$ Shihab, 2008,Vol.11,110
} 
be interpreted as knowing what is implied behind the explicit, seeing the unseen from seeing the real, knowing the certainty of the end because you have seen the beginning. Hamka also quoted Abduh's opinion that wisdom is a valid and accountable science, which has a very deep influence within oneself, so he determines the irada or willingness to choose what to do. If a deed is performed under valid knowledge, it will be a pious deed, which benefits and brings people to happiness ${ }^{45}$. According to Hamka, the part of the verse which means that "Allah gives wisdom to whom He wills", means being given the perfect tool as a human being. That tool is a reason and the one who is given the gift of reason among God's creatures is only humans. Intelligent reason is the most powerful tool for deepening true knowledge with doubts and suspicions. Intellect is a weighing tool, a set-off between doubts and correct conclusions, a set-off between what can be acknowledged and understood and what calls for a long reflection ${ }^{46}$.

The following table lists down the terms of teacher used in the Qur'an

\begin{tabular}{|c|c|c|c|}
\hline \multirow[t]{5}{*}{ Code } & Term in the Qur'an & Surah and Verse & Meaning \\
\hline & \multirow[t]{2}{*}{ آَلْعُعَمَأ } & al-Shu'arā 197 & $\begin{array}{l}\text { The ulama of Bani } \\
\text { Israel who knows the } \\
\text { nature of the Qur'an } \\
\text { as a divine revelation }\end{array}$ \\
\hline & & Fätir 28 & $\begin{array}{l}\text { Those who have } \\
\text { knowledge (religious, } \\
\text { natural, social } \\
\text { science) that leads to } \\
\text { fear and submission } \\
\text { to Allah }\end{array}$ \\
\hline & \multirow[t]{2}{*}{ مربي } & al-Fàtih 2 & $\begin{array}{l}\text { Rabb is related to } \\
\text { education. The word } \\
\text { rabb, which has } \\
\text { similar root to } \\
\text { tarbiyah, is to direct } \\
\text { something step by } \\
\text { step towards the } \\
\text { perfection of its } \\
\text { occurrence } \\
\text { function. }\end{array}$ \\
\hline & & ‘'̄ 1 li 'Imrān 79 & $\begin{array}{l}\text { It refers to an } \\
\text { educators } \\
\text { protectors, who and } \\
\text { blessed with books, } \\
\text { wisdom, } \\
\text { prophethood. They } \\
\text { encourage everyone }\end{array}$ \\
\hline
\end{tabular}

${ }^{45}$ Hamka, 2003, Juz 1, 539

${ }^{46}$ Hamka, 2003,Juz 1, 539 


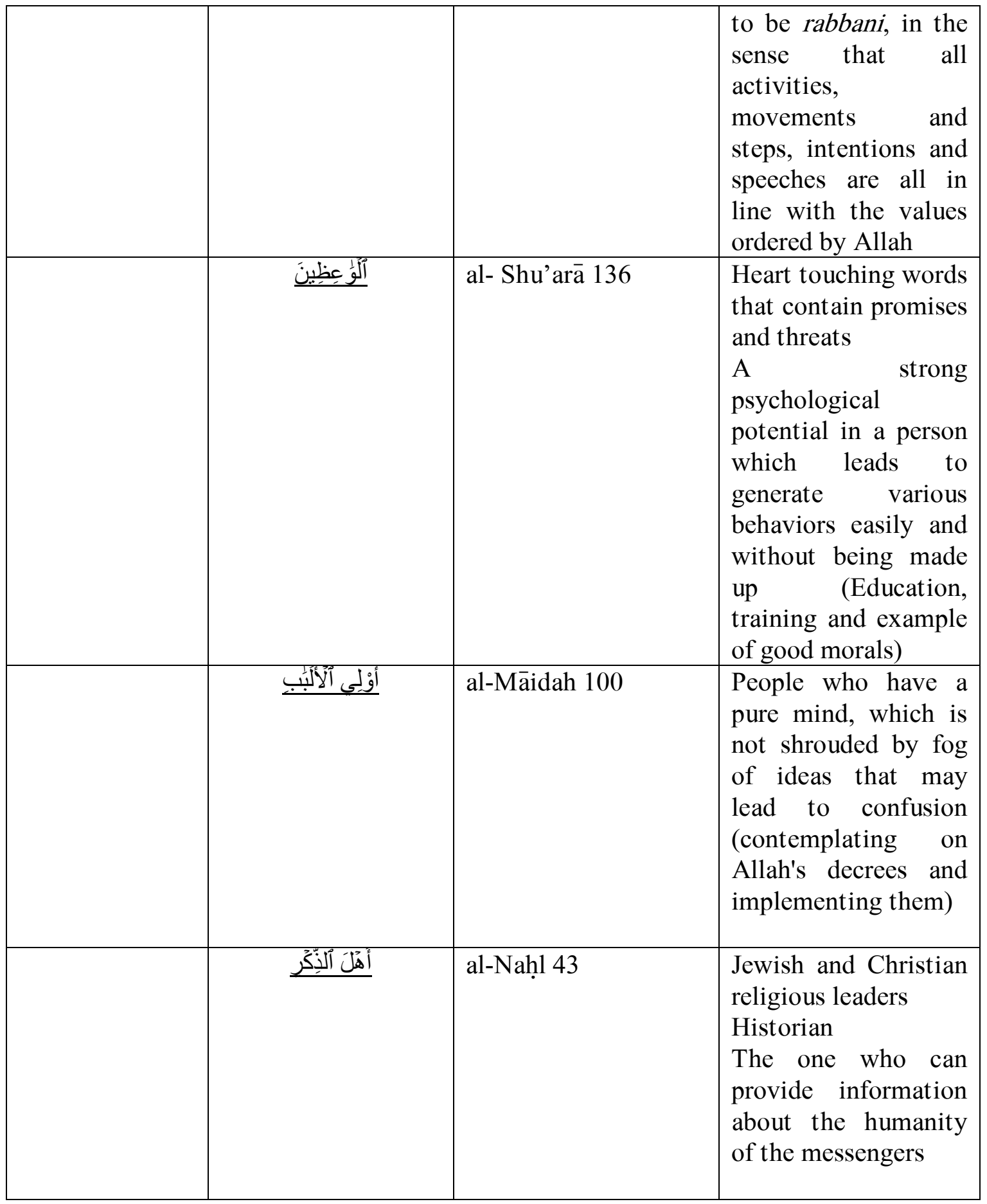

\section{Teachers' Role in Achieving the Comprehensive Education in the Digital Era}

Teachers in the perspective of the Qur'an are educators who are responsible for nurturing a student. They are figures who understand where students should be directed to. Knowledge of the purpose of education may be realized by students later after they go into adulthood. Adult students will realize that their treatment during the education period, even though it seems coercive, is good for them. Teachers are also described by the Qur'an with the task of honing the potential of students, so in the end 
the potential can generate various knowledge. Knowledge is not only at the theoretical level but also about truth and virtue. Thus, education does not only come to the mastery of knowledge but also the practice of truth and virtue. Humans have the potential to know theoretically and practice it. The teachers' duty is to lead students to achieve theoretical knowledge and practice of truth and virtue.

The Qur'an emphasizes the function and role of the teacher in the overall educational goal, which is the development of a complete person. A complete human development is the goal of education to cultivate the potential of students as a whole. Education does not only concern on the cognitive aspects of students. The development of student potential covers knowledge, skills, attitudes, and morals and characters of students ${ }^{47}$.

The overall role of teachers cannot be replaced by digital technology. Teachers are in charge of determining the success of achieving educational goals. They understand where students will be developed and directed for their future. Students need not only knowledge and skills but also goodness and moral development. Teachers who educate and nurture students can accompany them to form the expected character. Teachers play an important role in the establishment of educational institutions that produce civilized human beings ${ }^{48}$.

The role of teacher as a whole in achieving the goals of comprehensive education is a solution for character and moral education which is currently under threat. The results of the current study that emphasizes a teacher as a facilitator shows that the purpose of education so far has placed more emphasis on the cognitive and psychomotor aspects of students. Education which only focuses on the cognitive and psychomotor aspects ignores the character and moral aspects of students. Existing studies have actually shown the implications of learning that only focuses on cognitive and psychomotor aspects. However, character education is still not optimally developed $^{49}$.

The result of the research on the role of teachers in achieving comprehensive education suggests the need for institutional support. Educational institutions need to strengthen planning and evaluate the implementation of learning. Planning is realized by strengthening the curriculum oriented towards educational goals to create a complete human. Teachers are involved in planning and implementing learning. Teachers not only transfer knowledge but also nurture and foster students' characters and morals.

\footnotetext{
${ }^{47}$ Muhajir, 2011

${ }^{48}$ Mundzier Suparta, "Pendidikan Transformatif; Menuju Masyarakat Demokratis," Islamica; Jurnal Studi Keislaman 7, no. 2 (2013), https://doi.org/https://doi.org/10.15642/islamica.2013.7.2.406-425.

49 Irwan Abdullah et al., "Beyond School Reach: Character Education in Three Schools in Yogyakarta, Indonesia," Journal of Educational and Social Research 9, no. 3 (2019): 145-59, https://doi.org/10.2478/jesr-2019-0032.
} 


\section{Conclusion}

A teacher under the perspective of the Qur'an remains relevant in the digital era because he/she is not only a facilitator in learning but also an educator and caregiver of children. Learning aims to not only transfer knowledge but also direct the students' potential development to be complete human beings with knowledge, skills, and good attitudes, character, and morals. Guidance by the teacher does not imply the domination of the teacher and the passive position of the student. Active students are accompanied, nurtured and directed to achieve the expected value goals.

Through the Qur'anic perspective on teachers, this study views education more comprehensively. Education envisions to not only increase students' knowledge and skills but also build their character. The role of teachers as caregivers and directors is very much needed for character education because students are perceived to have insufficient knowledge on the values needed. The use of internet technology does not eliminate teachers' role because internet could be disastrous for students without their guidance and supervision. It can hinder the process of reaching the educational goals by undermining student's morale.

This study is limited to the textual study on the concept of the Qur'an, so it has a single textual perspective. It is, therefore, necessary to develop contextual or even living studies to examine a more comprehensive perspective on how the Qur'anic concept of teachers is perceived by educational institutions.

\section{REFERENCE}

Abdullah, Irwan, Bambang Hudayana, Setiadi, Pande Made Kutanegara, and Agus Indiyanto. "Beyond School Reach: Character Education in Three Schools in Yogyakarta, Indonesia." Journal of Educational and Social Research 9, no. 3 (2019): 145-59. https://doi.org/10.2478/jesr-2019-0032.

Al-Farmawi, A. H. Al-Bidâyah Fî At-Tafsîr Al-Maudhû'̂̂. Mesir: Maktabah Jumhuriyah, 1977.

Amin, Jayendrakumar N. "Redefining the Role of Teachers in the Digital Era." International Journal of Indian Psychology 3, no. 3 (2016). https://doi.org/10.25215/0303.101.

Cladis, Andrea E. "A Shifting Paradigm: An Evaluation of the Pervasive Effects of Digital Technologies on Language Expression, Creativity, Critical Thinking, Political Discourse, and Interactive Processes of Human Communications." $E-$ Learning and Digital Media 17, no. 5 (2020): 341-64. https://doi.org/10.1177/2042753017752583.

Gewasari, Miska, Belferik Manullang, and Abdul Muin Sibuea. "The Determinant Factors That Effect Teacher Performance of Public Senior High School in Deli Serdang District." IOSR Journal of Research \& Method in Education (IOSRJRME) 07, no. 01 (2017): 12-21. https://doi.org/10.9790/7388-0701041221.

Ghoni, A. "Pemikiran Pendidikan Naquib Al-Attas Dalam Pendidikan Islam Kontemporer." Jurnal Lentera: Kajian Keagamaan, Keilmuan Dan Teknologi 3, 
no. 1 (2017): 196-215.

Hamka. Tafsir Al-Azhar. Singapura: Pustaka Nasional, 2003.

- Tafsir Al-Azhar. Jakarta: Gema Insani, 2015.

Iqbal, Muhammad, and Muhammad Irfan Arif. "Globalization and Paradigm Changes in Teacher Education: Revolutionizing Teaching Learning Process at School Level in Pakistan." International Education Studies 4, no. 4 (2011): 99-110. https://doi.org/10.5539/ies.v4n4p99.

Irham, Irham, Sansan Ziaul Haq, and Yudril Basith. "Deradicalising Religious; EducationTeacher, Curriculum and Multiculturalism." Epistemé: Jurnal Pengembangan Ilmu Keislaman 15, no. 1 (2020): 39-54. https://doi.org/10.21274/epis.2020.15.1.39-54.

Jamaruddin, Ade. "Exsistensi Fungsi Akal Manusia Perspektif Al- Qur'an.” An-Nur 4, no. 1 (2015): 77-110.

Kusmaryani, Rosita Endang, Juke R Siregar, Hanna Widjaja, and Ratna Jatnika. "Key Factors in Teacher Professional Development." 2nd Psychology and Humanity, no. July 2014 (2016): 704-8.

Lestari, Putri, Nurul Iman, and Katni Katni. "Pemikiran Pendidikan Islam Syed Muhammad Naquib Al-Attas (Tinjauan Paradigmatik Dan Implementatif Konsep Ta'dib Dalam Pembelajaran Agama Islam Pada Tingkat SMA/MA)." TARBAWI:Journal on Islamic Education 3, no. 1 (2019): 17. https://doi.org/10.24269/tarbawi.v3i1.208.

Mardianto. "Peran Guru Di Era Digital Dalam Mengembangkan Self Regulated Learning Siswa Generasi Z Untuk Pencapaian Hasil Pembelajaran.” Prosiding Seminar Nasional \& Call Paper, 2019, 150-57.

Moll, Henrike. "How Young Children Learn from Others." Journal of Philosophy of Education 54, no. 2 (2020): 340-55. https://doi.org/10.1111/1467-9752.12417.

Mudlofir, Ali. "Tafsir Tarbawi Sebagai Paradigma Qur'ani Dalam Reformulasi Pendidikan Islam." Al-Tahrir: Jurnal Pemikiran Islam 11, no. 2 (2011): 261. https://doi.org/10.21154/al-tahrir.v11i2.35.

Muhajir, As'aril. "Tujuan Pendidikan Dalam Perspektif Al-Qur'an.” Al-Tahrir: Jurnal Pemikiran Islam 11, no. 2 (2011): 237. https://doi.org/10.21154/al-tahrir.v11i2.34.

Mujahidin, Anwar. "Integrative Education Paradigm Based on Local Culture; Analysis of Contextual Interpretation of Qur'anic Verses on the Purpose of Human Creation." Atlantis 261, no. Icie (2018): 163-68.

—. "The Dialectic of Qur' an and Science: Epistemological Analysis of Thematic Qur'an Interpretation Literature in the Field of Social Sciences of Humanities." ESENSIA: Jurnal Ilmu-IImu Ushuluddin 19, no. 2 (2018): 209. https://doi.org/DOI: https://doi.org/10.14421/esensia.v19i2.1563.

Munir, Muhammad. "Fenomena Dakwah Online Dan Offline Ustadz Abdus Somad Di Pondok Pesantren Al-Amien Prenduan Sumenep Madura Pendahuluan Ketenteraman Dalam Kehidupan Masyarakat Merupakan Salah Satu Harapan Seluruh Masyarakat Didunia , Tidak Juga Masyarakat Yang Di Kehidupan.” Islamic Management and Empowerment 1, no. 1 (2019): 129-42.

Mustafa, Sahidi Mustafa. "Konsep Jiwa Dalam Al-Qur'an." Tasfiyah 2, no. 1 (2018): 123. https://doi.org/10.21111/tasfiyah.v2i1.2485.

Pangrazio, Luci, Anna Lena Godhe, and Alejo González López Ledesma. "What Is Digital Literacy? A Comparative Review of Publications Across Three Language 
Contexts." E-Learning and Digital Media 17, no. 6 (2020): 442-59. https://doi.org/10.1177/2042753020946291.

Pito, Abdul Haris. "Metode Pendidikan Dalam Al-Qur'an." Andragogi: Jurnal Diklat Teknis Pendidikan Dan Keagamaan 7, no. 1 (2019): 113-29. https://doi.org/10.36052/andragogi.v7i1.74.

Prakoso, Theo Jaka. "Validitas Tafsir Bi Al-Ilmi Dalam Penafsiran Ayat-Ayat Penciptaan Alam." Studi Ilmu-Ilmu Al-Quran Dan Hadist 21, no. 1 (2020). https://doi.org/, doi: 10.14421/qh.2020.2101-04.

Raihani. "A Model of Islamic Teacher Education for Social Justice in Indonesia a Critical Pedagogy Perspective." Journal of Indonesian Islam 14, no. 1 (2020): 163-86. https://doi.org/10.15642/JIIS.2020.14.1.163-186.

Rustiana, Ade, Wisudani Rahmaningtyas, and Malinda Listia Astuti. "The Effect of Academic Qualification, School Facilities and Compensation on Teacher Professional Competency." Dinamika Pendidikan 13, no. 2 (2018): 157-70. https://doi.org/DOI: 10.15294/dp.v13i2.18328.

Shah, Kanchi, Junaid Ahmed, Nandita Shenoy, and Srikant N. "How Different Are Students and Their Learning Styles?" International Journal of Research in Medical Sciences 1, no. 3 (2013): 1. https://doi.org/10.5455/23206012.ijrms20130808.

Shenoy, Nandita, K. Ashok Shenoy, and U. P. Ratnakar. "The Perceptual Preferences in Learning among Dental Students in Clinical Subjects." Journal of Clinical and Diagnostic Research 7, no. 8 (2013): 1683-85. https://doi.org/10.7860/JCDR/2013/4940.3219.

Shihab, M. Quraish. Membumikan Al-Quran, Fungsi Dan Peran Wahyu Dalam Kehidupan Masyarakat. Bandung: Mizan, 2007.

—. Tafsir Al-Mishbah; Pesan, Kesan Dan Keserasian Al-Quran. Jakarta: Lentera Hati, 2008.

Subur. "Materi, Metode, Dan Evaluasi Pembelajaran Dalam Perspektif Al-Qur'an." Jurnal Penelitian Agama 16, no. $2 \quad$ (2015): 199. https://doi.org/10.24090/jpa.v17i1.2016.pp43-72.

Suparta, Mundzier. "Pendidikan Transformatif; Menuju Masyarakat Demokratis." Islamica; Jurnal Studi Keislaman 7, no. 2 (2013). https://doi.org/https://doi.org/10.15642/islamica.2013.7.2.406-425.

Syafa'ati, Sri, and Hidayatul Muamanah. "Konsep Pendidikan Menurut Muhammad Naquib Al-Attas Dan Relevansinya Dengan Sistem Pendidikan Nasional." Palapa:Jurnal Studi Keislaman Dan Ilmu Pendidikan 8, no. 2 (2020): 285-301. https://doi.org/10.36088/palapa.v8i2.859.

Syamsuddin, Sahiron. Tafsir Studies. Yogyakarta: eLSAQ, 2009.

Syarifuddin, M. Anwar, and Jauhar Azizy. "Thematic Scientific Interpretation of the Qur'an in Indonesia." Atlantis Press 137, no. Icqhs 2017 (2018): 43-50. https://doi.org/10.2991/icqhs-17.2018.7. 